\title{
Penguatan Desa Wisata Berbasis Kampung Iklim: Menuju Terwujudnya Ketahanan Pangan di Desa Pandowoharjo Sleman Yogyakarta
}

\author{
B. Tresno Sumbodo ${ }^{\# 1}$, Sardi ${ }^{\# 2}$, Sunarya ${ }^{\# 3}$, Hermawan Prasetyanto ${ }^{* 4}$ \\ ${ }^{1}$ tresno@janabadra.ac.id \\ ${ }^{2}$ sardi@janabadra.ac.id \\ ${ }^{3}$ sunarya@janabadra.ac.id \\ ${ }^{4}$ hermawan.prasetyanto@yahoo.co.id \\ ${ }^{\# 1}$ Agribisnis,Universitas Janabadra Yogyakarta \\ ${ }^{\# 1}$ Teknik Sipil,Universitas Janabadra Yogyakarta

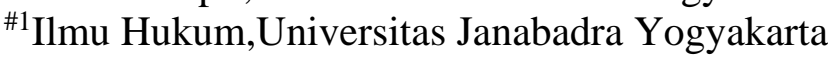 \\ ${ }^{* 4}$ Perhotelan, STP AMPTA Yogyakarta
}

\begin{abstract}
Every household always hopes to have enough food available. While fertile agricultural land is decreasing, food needs increase with increasing population. The use of the yard is expected to help improve food availability for the community.

In realizing a climate village tourism village in Pandowoharjo Village, a series of activity programs are designed to be carried out continuously for three years. In Year I of the program, community education activities focused on harvesting and using rainwater for vegetable cultivation in the yard. The design of rainwater harvesting facilities is carried out in the form of IPAH, infiltration wells and dead-end channels (Rorak) in six padukuhan which have been designated as the center of tourism village development namely: Brayut, Temon, Pajangan, Dukuh, Karangtanjung and Plalangan.

This method of mentoring the PPDM scheme in Pandowoharjo was carried out in three stages, namely program socialization, training and implementation. The mentoring process is carried out with two approaches, namely theoretical training and skills improvement with practice in the field.

The results of the activities in Year I of the PPDM program have benefited partners directly, including: a) Increasing number of people who understand, and have skills in responding to climate change; b) Number of facilities for IPAH, infiltration and rorak wells increased by 15 units; c) The number of people who harvest and utilize rainwater increases by $15 \mathrm{KK} ; d$ ) The number of members of the farmer group of women who use the yard for the cultivation of vegetables with vertikulture and hydroponic systems increases by 20 people.

Some achievements that are non-physical such as: network of rainwater harvesters, improvement of knowledge and skills of community members, and pilot cooperation partnerships that integrate several productive economic business groups with BUMDes.
\end{abstract}

Keywords: climate village, food availability, mentoring, productive economy,village tourism. 


\section{PENDAHULUAN}

Ketersediaan pangan dalam jumlah cukup sepanjang waktu merupakan keniscayaan yang tidak terbantahkan, setiap rumah diharapkan mengoptimalkan pemanfaatan lahan pekarangan untuk menyediakan pangan bagi keluarga [1].

Terdapat hubungan positif antara variasi pemanfaatan lahan pekarangan dengan ketahanan pangan, semakin tinggi variasi pemanfaatan pekarangan yang dilakukan semakin tinggi pula tingkat ketahanan pangan keluarga [2].

Kebutuhan air baku bagi masyarakat maupun air irigasi bagi para petani sangat tergantung kepada sumber-sumber mata air. Ketika masuk musim kemarau beberapa sumur warga mulai menipis ketersediaan airnya. Hal tersebut diakibatkan oleh minimnya peresapan air hujan ke dalam tanah, air hujan terus mengalir dan melimpas ke jalan-jalan desa kemudian hilang dari wilayah desa masuk ke sungai.

Kegiatan pendampingan masyarakat dengan skema PPDM ini bertujuan untuk mengintegrasikan pengembangan Kampung Iklim dengan usaha-usaha ekonomi produktif, memaksimalkan keterlibatan warga dalam pemanfaatan air hujan untuk kegiatan pertanian lahan pekarangan menuju ketahanan pangan dan pengembangan desa sebagai kampung wisata.

Program ini dirancang untuk tiga tahun, Tahun I fokus pada upaya panen dan pemanfaatan air hujan untuk pengelolaan lahan pekarangan dengan budidaya sayuran pada berbagai media vertikurtur dan hidroponik. Kegiatan ini diawali dengan rancang bangun dan pemanfaatan Instalasi IPAH, peresapan serta pembuatan saluran buntu (rorak) sebagai sarana edukasi masyarakat bagaimana mensikapi perubahan iklim yang terjadi disekitarnya. Tahun II program dilanjutkan dengan mengintegrasikan sistem pertanian terpadu melalui pengolahan sampah dan kotoran ternak menjadi pupuk organik. Melanjutkan rancang bangun dan pemanfaatan Instalasi IPAH, peresapan serta pembuatan saluran buntu (rorak) serta mengupayakanmodelmodel kerjasama kemitraan antara Kelompok Tani Sayuran, Kelompok Tani Ikan, Kelompok Tani Ternak, dengan BUMDes "Amarta". Tahun III menlanjutkan rancang bangun dan pemanfaatan Instalasi IPAH, peresapan serta pembuatan saluran buntu (rorak) dan pengembangan budidaya jamur. Budidaya jamur diawali dengan mewujudkan tersedianya baglog. Fokus pada tahun III pada pendampingan membangun jejaring kerjasama kemitraan antara Kelompok Tani Jamur dengan BUMDes dan industri rumah makan, serta pendampingan secara kelembagaan mendorong tumbuh dan berkembangnya unit-unit pengelola pariwisata.

Secara umum, kondisi usahatani di Desa Pandowoharjo berupa usahatani campuran yang terdiri dari pertanian tanaman pangan, perkebunan, peternakan dan perikanan. Komoditas yang diusahakan didominasi tanaman padi, sayuran, palawija dan hortikultura.

Kampung Iklim yaitu kampung yang terbentuk dari partisipasi aktif masyarakat dan seluruh pihak untuk meningkatkan ketahanan terhadap dampak perubahan iklim. Desa Pandowoharjo yang terdiri atas 17 Padukuhan pantas menjadi Kampung Iklim karena masyarakatnya secara aktif dan arif beradaptasi dengan alam. Jiwa sosial masih sangat kuat ditunjukkan masyarakat dalam berbagai kegiatan dengan bergotong-royong.

Melalui PPDM ini,tim pendamping bersama-sama masyarakat membuat Instalasi Pemanen Air Hujan (IPAH), peresapan, saluran buntu/rorak dan memanfaatkannya untuk pengelolaan lahan pekarangan. Penguatan Desa wisata 
berbasis Kampung Iklim dalam PPDM ini diprioritaskan pada upaya pemanenan air hujan dan pemanfaatannya untuk pengelolaan lahan pekarangan dengan berbagai kegiatan ekonomi produktif tanaman sayuran, perikanan, peternakan dan pariwisata.

\section{TINJAUAN PUSTAKA}

Pendapatan usahatani lahan pekarangan belum memberikan sumbangan cukup besar terhadap total pendapatan keluarga dibandingkan sumber pendapatan dari non pertanian dan dari usahatani non pekarangan. Usahatani pekarangan belum menjadi usahatani komersial dan sebagian besar petani $(64 \%)$ memiliki sumber pendapatan tetap dengan bekerja di sektor non pertanian dan usahatani masih berkonsentrasi pada lahan pertanian sawah [3].

Menurut Irwan, dkk. dalam penelitian yang dilakukan di Desa Mangunan, pemanfaatan lahan pekarangan dilakukan dengan berbagai tanaman yaitu tanaman buah $31 \%$, tanaman rempah $20 \%$, tanaman hias $15 \%$, dan sayuran 6\% [4].

Program Kampung Iklim (ProKlim) adalah program berlingkup nasional yang dikelola oleh Kementerian Lingkungan Hidup dan Kehutanan dalam rangka meningkatkan keterlibatan masyarakat dan pemangku kepentingan lain untuk melakukan penguatan kapasitas adaptasi terhadap dampak perubahan iklim dan penurunan emisi gas rumah kaca serta memberikan pengakuan terhadap upaya adaptasi dan mitigasi perubahan iklim yang telah dilakukan untuk meningkatkan kesejahteraan masyarakat [5]. Kampung Iklim adalah lokasi yang berada di wilayah administratif paling rendah setingkat rukun warga atau dusun dan paling tinggi setingkat kelurahan atau desa, atau wilayah yang masyarakatnya telah melakukan upaya adaptasi dan mitigasi perubahan iklim secara berkesinambungan [6].

Desa Pandowoharjo, mempunyai penduduk 13.164 jiwa, jumlah kepala keluarga 2.635 KK. sebagian besar bekerja sebagai petani.Desa Pandowoharjo, merupakan kawasan permukiman yang berada di antara perkotaan dan perdesaan di Kabupaten Sleman D.I. Yogyakarta [7].

Sesuai dengan RPJMDes Desa Pandowoharjo Tahun 2015-2020 dalam rangka meningkatkan kesejahteraan masyarakat dan pengembangan kawasan, Desa Pandowoharjo akan dikembangkan menjadi Desa Wisata berbasis Pertaniandan Desa Budaya [8].

Pencanangan wisata edukasi kampung iklim ini selaras dengan program dan strategi Pemerintah Kabupaten Sleman sebagaimana tertuang dalam RPJMD Kabupaten Sleman 2016-2021. Dalam RPJMD tersebut, strategi pertama pengembangan pariwisata adalah meningkatkan destinasi pariwisata dengan arah kebijakan meningkatkan pengelolaan destinasi pariwisata. Stategi kedua, meningkatkan kualitas desa wisata dengan arah kebijakan meningkatkan kategori desa wisata [9].

Bangunan sumur resapan adalah salah satu rekayasa teknik konservasi air berupa bangunan yang dibuat sedemikian rupa sehingga menyerupai bentuk sumur gali dengan kedalaman tertentu yang berfungsi sebagai tempat menampung air hujan yang jatuh di atas atap rumah atau daerah kedap air dan meresapkannya ke dalam tanah [10].Prinsip dasar sumur resapan adalah menyalurkan dan menampung curah hujan ke dalam sebuah sumur dengan tujuan agar air hujan memiliki waktu tinggal di permukaan tanah lebih lama sehingga sedikit demi sedikit air dapat meresap ke dalamtanah [11] 
Lebih lanjut ilustrasi dari prinsip kerja sumur resapan yang bersumber dari Kusnaedidigambarkan sebegai berikut [12]

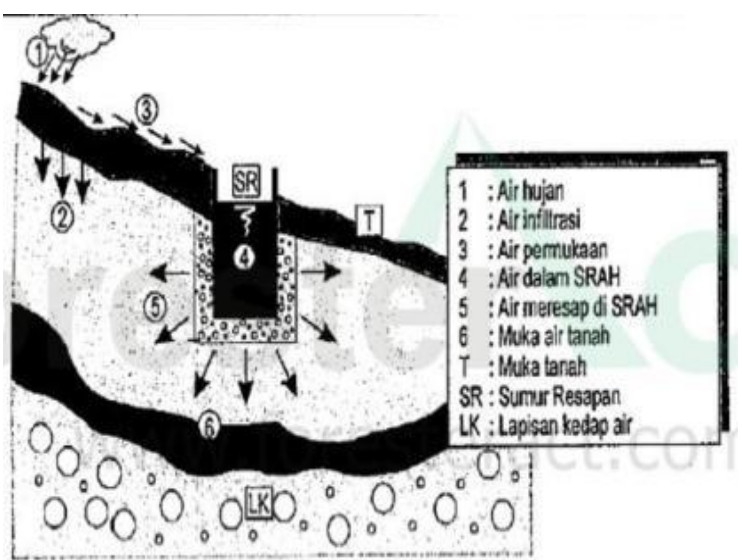

Kusnaedi (2011).

Menurut Supardi (2010), sumur resapan dapat dibuat dari berbagai macam bahan yang ada dilokasi, yang perlu diperhatikan adalah keamanan sumur resapan, perlu dilengkapai dengan dinding. Bahan material yang diperlukan meliputi: a. Saluran pemasukan / pengeluaran dapat menggunakan pipa GIP, PVC buis beton, pipa tanah liat atau dari pasangan baru;b. Dinding sumur dapat digunakan anyaman bambu, drum bekas, tangki fiberglass, pasangan batu, atau buis beton; dan c. Dasar sumur dan sela-sela antara galian tanah dan dinding dapat diisi dengan ijuk atau krikil [13].

Penentuan lokasi dan desain sumur bangunan resapan mengacu pada SNI No. 03-2453-2002 tentang Tata Cara Perencanaan Sumur Resapan Air Hujan untuk Lahan Pekarangan [14]. Persyaratan umum yang harus dipenuhi antara lain: a) Sumur resapan air hujan ditempatkanpada lahan yang relatif datar; b) Air yang masuk ke dalam sumur resapanadalah air hujan tidak tercemar; c) Penetapan sumur resapan air hujan harusmempertimbangkan keamanan bangunan sekitarnya;d) Harus memperhatikan peraturan daerah setempat; dan e) Hal-hal yang tidak memenuhi ketentuan ini harus disetujui instansi yang berwenang.

Sedangkan persyaratan teknis yang harus dipenuhi antara lain : a. Kedalaman air tanah minimum 1,50 mpada musim hujan; b. Struktur tanah yang dapat digunakanharus mempunyai nilai permeabilitas tanah $\geq 2,0 \mathrm{~cm} / \mathrm{jam}$. Artinya, genangan air setinggi $2 \mathrm{~cm}$ akan teresap habis dalam 1 jam. Adapun 3 klasifikasi nilai permeabilitas, yaitu: 1) Permeabilitas tanah sedang (geluhkelanauan), yaitu 2,0 - 3,6 cm/jam atau $0,48-0,864 \quad \mathrm{~m} 3 / \mathrm{m} 2 /$ hari.2) Permeabilitas tanah agak cepat (pasir halus), yaitu $3,6-36 \mathrm{~cm} / \mathrm{jam}$ atau 0,864 - 8,64 m3/m2/hari.3) Permeabilitas tanah cepat (pasir kasar), yaitu lebih besar dari $36 \mathrm{~cm} / \mathrm{jam}$ atau 8,64 $\mathrm{m} 3 / \mathrm{m} 2 /$ hari; dan c. Jarak penempatan sumur resapan air hujan terhadap bangunan ialah $3 \mathrm{~m}$ untuk sumur resapan air, $1 \mathrm{~m}$ untuk sumur air bersih, dan $5 \mathrm{~m}$ untuk pondasi.

Pembuatan sumur resapan merupakan salah satu cara yang efektif untuk meningkatkan kapasitas infiltrasi lahan, yang selanjutnya dapat menambah cadangan air tanah. Selain itu, sumur resapan berfungsi untuk mengurangi volume dan kecepatan aliran permukaan sehingga menurunkan puncak banjir [15].

\section{METODE}

Beberapa kegiatan pelatihan baik tentang teknik penangkap air hujan maupun pelatihan bidang pertanian, peternakan dan perikanan dilakukan secara bertahap dan berkesinambungan..

Kegiatan pendampingan skema PPDM di Pandowoharjo ini dilakukan dalam tiga tahap yaitu sosialisasi (perkenalan program), pelatihan dan implementasi [16]. Tahap pertama, perkenalan program 
kepada mitra dan kelompok sasaran dengan memberikan gambaran kegiatan apa dan bagaimana akan dilaksanakan agar masyarakat memahami dengan baik sehingga dapat berperan aktif dalam semua kegiatan.

Tahap kedua, pelatihan, dilakukan dengan menempatkan peserta sebagai subyek pendidikan, sementara tutor berperan sebagai fasilitator. Yang aktif belajar adalah para peserta, sehingga dalam pelaksanaannya materi teoritis hanya diberikan sebagai pengantar, dilanjutkan denga materi praktik, diskusi dan sumbang saran. Penjelasan tentang materi oleh tutor hanya disampaikan di awal pertemuan sebagai panduan untuk memasuki materi praktik. Dengan pendekatan tersebut tim pendamping memperkenalkan kepada mitra dan kelompok sasaran tentang sistim panen air hujan untuk pemanfaatan lahan pekarangan. Selain itu masyarakan juga diajarkan bagaimana memanfaatkan pekarangan rumah menjadi kebun sayuran yang produktif dengan sistem teknologi pertanian yaitu vertikultur dan hidroponik.

Kegiatan ini dimaksudkan sebagai sarana edukasi dengan memberikan pengetahuan dan keterampilan kepada masyarakat kelompok sasaran tentang teknik-teknik panen air hujan dan budidaya tanam sayuran dengan sistem vertikultur/hidroponik. Kegiatan dimulai dari pembuatan intalasi IPAH, sumur dan saluran resapan, media vertikultur dan hidroponik. Kemudian dilanjutkan dengan cara penyemaian benih tanaman hidroponik, pemilihan jenis-jenis tanaman, persiapan penanaman, pemberian nutrisi pada tanaman serta penyiraman hara otomatis, pembuatan nutrisi organik, pengendalian hama dan penyakit, teknik pemeliharaan tanaman serta cara pembuatan nutrisi / pupuk cair.

Tahap ketiga adalah implementasi, bentukaplikasi di lapangan atas apa yang telah dilatihkan dengan pendampingan oleh tim pendamping. Dalam hal pemanfaatan pekarangan dengan vertikultur dan hidroponik sayuran dimulai dari penyemaian benih, persiapan media, penanaman sampai pemeliharaan tanaman. Implementasi kegiatan model pertanian vertikultur dan hidroponik dilakukan dengan sistim demplot (percontohan) di beberapa rumah anggota kelompok wanita tani (KWT). Model hidroponik yang diaplikasikan disesuaikan dengan ketersediaan bahan dan kondisi pekarangan rumah, sedang pemilihan jenis sayuran yang akan ditanam dimusyawarahkan dalam kelompok sehingga dalam satu kelompok terdapat berbagai jenis sayuran yang diusahakan. Setelah mempraktikan budidaya tanaman secara vertikultur dan hidroponik akan terus mendapatkan bimbingan oleh tim pelaksana program melalui kegiatan pendampingan. Pendampingan dilakukan selama periode penanaman, pemeliharaan hingga panen sayuran dilakukan agar diperoleh hasil maksimal, dan untuk tahap selanjutnya diharapkan kelompok akan melakukannya secara mandiri dengan membagi pengetahuan dan ketrampilan kepada anggota yang lain.

Tiga strategi utama ditempuh dalam pelaksanaan program :pertama, pembinaan khalayak sasaran dengan pendampingansebagai upaya meningkatkan kesadaran masyarakat sehingga sebelum, saat maupun setelah pelaksanaan program warga mampu secara mandiri mengelola dan merawat Instalasi Pemanen Air Hujan, peresapan dan saluran buntu/rorak.Kedua, perintisan kemitraan dengan menjalin hubungan kerjasama dengan setiap pihak terkait, seperti Dinas Lingkungan Hidup Kabupaten, Komunitas Masyarakat Pemanen Air Hujan dan Sungai, BUMDes ataupun mitra lain sebagai permulaan dan 
membuka sarana kepada mitra untuk berkontribusi ikut bersinergi dalam program.Ketiga, monitoring dan evaluasi berdasarkan indikator keberhasilan program.

Tabel I

Tahapan Pelaksanaan, Metode Dan Hasil

\begin{tabular}{|c|c|c|}
\hline Tahap & Metode Pelaksanaan & Hasil Yang Diharapkan \\
\hline $\begin{array}{l}\text { Tahap } \\
\text { Awal }\end{array}$ & $\begin{array}{lr}\text { a. Melakukan } & \text { pendekatan } \\
\text { dan sosialisasi } & \text { terhadap } \\
\text { pemerintah } & \text { dan } \\
\text { masyarakat } & \text { tentang } \\
\text { kegiatan } & \text { transfer } \\
\text { teknologi } & \\
\end{array}$ & $\begin{array}{l}\text { a. Apresiasi, kesiapan dan } \\
\text { penerimaan deangan baik } \\
\text { dari pemerintah desa dan } \\
\text { masyarakat } \\
\begin{array}{ll}\text { rencana } & \text { tentang } \\
\text { teknologi } & \text { transfer } \\
\end{array}\end{array}$ \\
\hline $\begin{array}{l}\text { Tahap } \\
\text { Pelaksa } \\
\text { naan }\end{array}$ & $\begin{array}{l}\text { a. Melakukan sosialisasi } \\
\text { tentang program transfer } \\
\text { teknologi kepada } \\
\text { masyarakat } \\
\text { b. Melakukan kegiatan } \\
\text { transfer teknologi dan } \\
\text { pendampingan tentang : } \\
\text { sistim panen air hujan, } \\
\text { budidaya sayuransistim } \\
\text { vertikultur dan } \\
\text { hidroponik, budidaya } \\
\text { ikan dan ternak, } \\
\text { pengelolaan sampah, } \\
\text { budidaya jamur, jejaring } \\
\text { kerjasama kemitraan, } \\
\text { serta pengelolaan desa } \\
\text { wisata }\end{array}$ & $\begin{array}{l}\text { a. Masyarakat mendapatkan } \\
\text { gambaran lengkap } \\
\text { program kegiatan } \\
\text { b. Pengetahuan dan } \\
\text { ketrampilan masyarakat } \\
\text { dalam mensikapi } \\
\text { perubahan iklim } \\
\text { meningkat } \\
\text { c. Pengetahuan } \\
\text { ketrampilan masyarakat } \\
\text { tentang sistim budidaya } \\
\text { vertikultur } \\
\text { hidroponik meningkat } \\
\text { d. Pengetahuan } \\
\text { ketrampilan masyarakat } \\
\text { dalam budidaya jamur, } \\
\text { budidaya ikan dan ternak } \\
\text { meningkat }\end{array}$ \\
\hline $\begin{array}{l}\text { Tahap } \\
\text { Akhir }\end{array}$ & $\begin{array}{l}\text { a. Melakukan monitoring } \\
\text { dan evaluasi }\end{array}$ & $\begin{array}{l}\text { a. Masyarakat terampil } \\
\text { dalam budidaya sayuran } \\
\text { sistim vertikultur dan } \\
\text { hidroponik rumah } \\
\text { b. Tersedianya ba rong } \\
\text { produksi baglog yang } \\
\text { dapat mensuplai } \\
\text { kebutuhan petani jamur } \\
\text { c. Terwujudnya desa wisata } \\
\text { berbasis pertanian yang } \\
\text { mampu menggerakkan } \\
\text { roda kegiatan ekonomi } \\
\text { d. Terjalinnya kerjasama } \\
\text { kemitraan unit-unit usaha } \\
\text { produktif }\end{array}$ \\
\hline
\end{tabular}

\section{HASIL}

Sesuai dengan RPJMDes Desa Pandowoharjo Tahun 2015-2020 dalam rangka meningkatkan kesejahteraan masyarakat dan pengembangan kawasan, Desa Pandowoharjo akan dikembangkan menjadi Desa Wisata berbasis Pertaniandan Desa Budaya.Melalui program PPDM ini dipilih 4 (empat) padukuhan di Desa Pandowoharjo yang dicanangkan sebagai desa wisata yaitu: Brayut sebagai Desa
Wisata berbasis Budaya Pertanian, Temon sebagai Desa Wisata Kampung Bocah, Pajangan dengan Desa Wisata Budaya, dan Dukuh dengan Desa Wisata Pendidikan. Disamping itu, 2 (dua) padukuhan sebagai rintisan desa wisatayaitu:Karangtanjungdengan Desa Wisata Kampung Iklim dan Plalangan dengan Desa Wisata Budaya berbasis ekonomi kreatif.

Padukuhan Brayut memiliki potensi wisata budaya berbasis pertanian menjadi salah satu desa wisata yang ramai dikunjungi dengan berbagai aktifitas yang ditawarkan seperti belajar bertani, membatik, karawitan, tari tradisional dan sudah dilengkapi dengan fasilitas homestay, sanggar tari, sanggar karawitan, alam persawahan lengkap dengan perlatan tani tradisonal, dan toko souvenir. Padukuhan Temonmemiliki potensi wisata kampung bocah, disini berbagai macam dolanan anak tradisional bisa dinikmati. Dengan paket live-in maupun kunjungan sehari, pengunjung bisa bermain aneka permainan anak tradisional, disamping aktivitas pertanian, perkebunan, peternakan dan pengolahan hasil bumi, serta susur sungai.Suasana khas pedesaan masih sangat terasa, halaman cukup lapang, rumah Joglo atau limasan dan pepohonan hijau segardan nyaman. Fasilitas homestay, ada 33 rumah yang siap sebagai homestay dengan kapasitas tamu hingga \pm 120 anak. PadukuhanPajanganmemiliki potensi wisata budaya yang sudah cukup terkenal yaitu kesenian tradisional wayang kulit/pedalangan, ketoprak, dan karawitan. PadukuhanDukuh15km ke arah Utara dari pusat Kota Yogja.Tempat ini sangat cocok untuk sarana edukasi pelajarmulai dari TK sampai SMA. Terdapat usaha pembuatan tempe secara tradisional, peternakan sapi perah,pembuatan lilin,budidaya jamur, dan edukasi pertanian yang dapat diajarkan kepada anak-anak perkotaan. PadukuhanKarangtanjung memiliki potensi wisata kampung iklim dan edukasi, didukung dengan kondisi lingkungan alam 
dan kearifan lokal 'gotong-royong' yang masih menjadi tradisi kuat semua warga. Cukup banyak kelompok masyarakat: Pokdarwis Kampung Iklim Sumber Air Karang Tirto, Kelompok Tani Mekar Tanjung, Kelompok Wanita Tani Karang Tanjung, Kelompok Ternak Andhini Mulyo, dan Kelompok Tani Perikanan.Serupa dengan padukuhan Pajangan, Plalangan dijadikan sebagai rintisan Desa Wisata Budaya berbasis ekonomi kreatif memiliki cukup banyak potensi usaha ekonomi produktif dan budaya antara lain: bank sampah, batik, dan sanggar kerawitan.

TABEL III

Pemetaan Potensi Desa Wisata di pandowoharjo

\begin{tabular}{|c|c|c|c|}
\hline \multirow{2}{*}{ No. } & \multicolumn{3}{|c|}{ Potensi dan Skala Prioritas Pengembangan } \\
\hline & Padukuhan & Protensi & Skala Prioritas \\
\hline 1 & Brayut & $\begin{array}{l}\text { Desa wisata } \\
\text { budaya }\end{array}$ & $\begin{array}{l}\text { Pertanian lahan } \\
\text { pekarangan, } \\
\text { batik, karawitan }\end{array}$ \\
\hline 2 & Temon & $\begin{array}{l}\text { Desa wisata } \\
\text { kampung } \\
\text { bocah }\end{array}$ & $\begin{array}{l}\text { Dolanan anak } \\
\text { tradisonal }\end{array}$ \\
\hline 3 & Pajangan & $\begin{array}{l}\text { Desa wisata } \\
\text { budaya }\end{array}$ & $\begin{array}{l}\text { Wayang } \\
\text { /pedalangan, } \\
\text { ketoprak, } \\
\text { karawitan }\end{array}$ \\
\hline 4 & Dukuh & $\begin{array}{l}\text { Desa wisata } \\
\text { edukasi dan } \\
\text { ekonomi } \\
\text { kreatif }\end{array}$ & $\begin{array}{l}\text { Tempe, ternak, } \\
\text { lilin, jamur }\end{array}$ \\
\hline 5 & Karangtanjung & $\begin{array}{l}\text { Desa wisata } \\
\text { kampung } \\
\text { iklim }\end{array}$ & $\begin{array}{l}\text { Kearifan lokal } \\
\text { pengelolaan } \\
\text { alam } \\
\text { lingkungan }\end{array}$ \\
\hline 6 & Plalangan & $\begin{array}{l}\text { Desa wisata } \\
\text { budaya }\end{array}$ & $\begin{array}{l}\text { Bank sampah, } \\
\text { batik, sanggar } \\
\text { karawitan }\end{array}$ \\
\hline
\end{tabular}

Disamping 6 (enam) padukuhan tersebut, masih terdapat satu padukuhan yang sangat terkenal dalam dunia wisata kuliner di Yogyakarta yaitu Padukuhan Niron. PadukuhanNironmemiliki potensi wisata kuliner rumah makan"jejamuran" yang cukup terkenal di Yogyakarta, salah satu daya tarik kuat para wiasatawan datang ke Desa Pandowoharjo dan padukuhan- padukuhan di dalamnya.Banyak wisatawan datang menikmati keistimewaan menu yang disajikan berbahan utama jamur. Rumah makan ini terus mengalami perkembangan, namunkebutuhan bahan baku jamur rumah makan tersebut sebagian masih harus didatangkan dari luar daerah.Masih terbuka luas bagi masyarakat warga setempat untuk terlibat memasok bahan baku jamur ke rumah makan tersebut. Namun hingga saat ini, potensi tersebut belum dimanfaatkan karena adanya kendala ketersediaan baglog dalam jumlah yang sangat terbatas.

Pencanangan wisata edukasi kampung iklim ini selaras dengan program dan strategi Pemerintah Kabupaten Sleman sebagaimana tertuang dalam RPJMD Kabupaten Sleman 2016-2021.Ada dua strategi terkait dengan pengembangan desa wisata yang dituangkan dalam RPJMD:Strategi pertama pengembangan pariwisata adalah meningkatkan destinasi pariwisata dengan arah kebijakan meningkatkan pengelolaan destinasi pariwisata. Stategi kedua, meningkatkan kualitas desa wisata dengan arah kebijakan meningkatkan kategori desa wisata. Urusan lingkungan hidup, salah satu strateginya adalah melaksanakan percepatan pengelolaan air minum, air limbah, persampahan dan lingkungan hidup dengan arah kebijakan menyediakan IPAL komunal, sambungan air minum, tempat pembuangan sampah dan meningkatkan Indeks Kualitas Lingkungan Hidup.

Beberapa kegiatan pelatihan dan pendampingan dilakukan terkait teknik penangkap air hujan maupun pelatihan bidang pertanian :

1. Mengintegrasikan pengembangan Kampung Iklim dengan usaha-usaha ekonomi produktif, dengan memaksimalkan keterlibatan warga dalam pemanfaatan air hujan untukkegiatan pertanianpada lahan pekarangan menuju terciptanya ketahanan pangan di Desa Pandowoharjo. 
2. Meningkatkan pemanfaatan air hujan dengan meresapkan sebanyak mungkin ke dalam tanah agar bisa dipanen pada sumur-sumur warga saat musim kemarau dan menjaga keberlangsungan sumber-sumber mata air di Desa Pandowoharjo dan wilayah sekitarnya.

3. Memberi edukasi kepada masyarakat/warga bagaiamana melakukan adaptasi terhadap perubahan iklim yang terjadi.

4. Melakukan rancang bangun Instalasi Pemanen Air Hujan (IPAH), peresapan serta pembuatan saluran buntu/rorak dilahan pekarangan warga agar saat hujan air tidak melimpas ke jalan-jalan kemudian masuk sungai dan hilang dari wilayah desa.

5. Meningkatkan kepedulian dan keterlibatan warga akan pentingnya pengelolaan air hujan dan pekarangan dengan bijaksana untuk menjaga kelestarian lingkungan melalui: sosialisasi, mock-up dan publikasi proses serta hasil kegiatan adaptasi lingkungan yang dilakukan.

Pada Tahun I program PPDM ini telah dilaksanakan beberapa kegiatan bagi pengembangan Desa Wisata Kampung Iklim berbasis budaya dan lingkungan berupa :

1. Sarana IPAH, peresapan dan saluran buntu/rorak pada lahan pekarangan rumah warga yang dapat dimanfaatkan secara optimal untuk kegiatan pertanian, perikanan dan pariwisata.

2. Buku manual teknis pembuatan dan pemeliharaan IPAH, peresapan dan saluran buntu/rorak agar pemanfaatan dan pengelolaan air hujan.

3. Profil dan poster Desa Wisata Kampung Iklim, sebagai dokumentasi pembelajaran bagi masyarakat sekitar, para wisatawan yang datang maupun bagi masyarakat luas.

4. Jejaring penggiat pemanen air hujan untuk menopang kegiatan pertanian, perikanan dan pariwisata (membentuk atau bergabung dengan grup komunitas kegitan sejenis) yang di dalamnya terdiri dari berbagai kalangan seperti akademisi, parktisi, birokrasi dan masyarakat.

5. Peningkatan pengetahuan dan ketrampilan warga masyarakat dalam budidaya tanaman sayuran dan pangan.

6. Rintisan kerjasama kemitraan yang mengintegrasikan berbagai kegiatan diantara beberapa kelompok usaha ekonomi produktif dengan BUMDes, industri kuliner dan kelompokkelompoksadar wisata (pokdarwis) di Desa Pandowoharjo.

\section{Instalasi Pemanen Air Hujan (IPAH)}

Prinsip dalam pemanfaatan air hujan adalah air ditabung di musim hujan, untuk dipanen di musim kemarau.

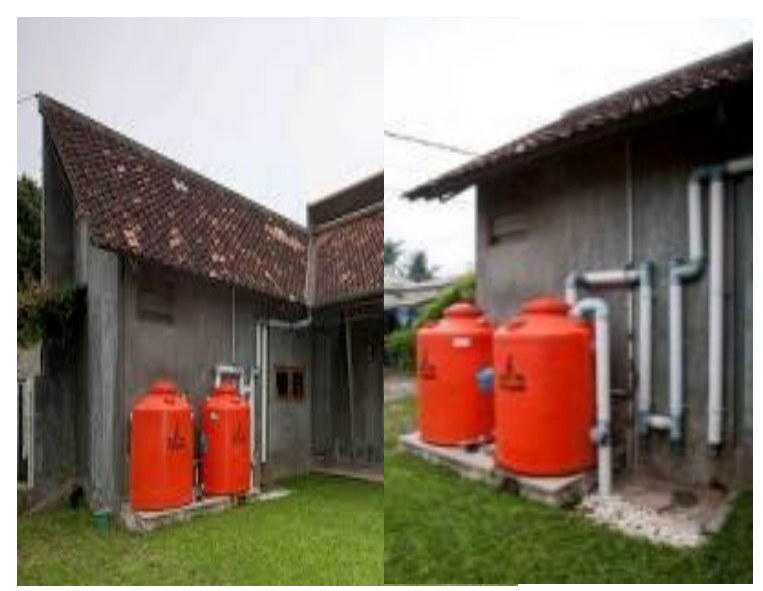

Gambar 1.Model IPAH dengan Saluran Paralon dan Tangki Plastik

Salah satu rekayasa teknik konservasi air berupa bangunan yang dibuat sedemikian rupa sehingga menyerupai bentuk sumur gali dengan kedalaman tertentu yang berfungsi sebagai tempat menampung air hujan yang jatuh di atas atap rumah atau daerah kedap air dan meresapkannya ke dalam tanah. 


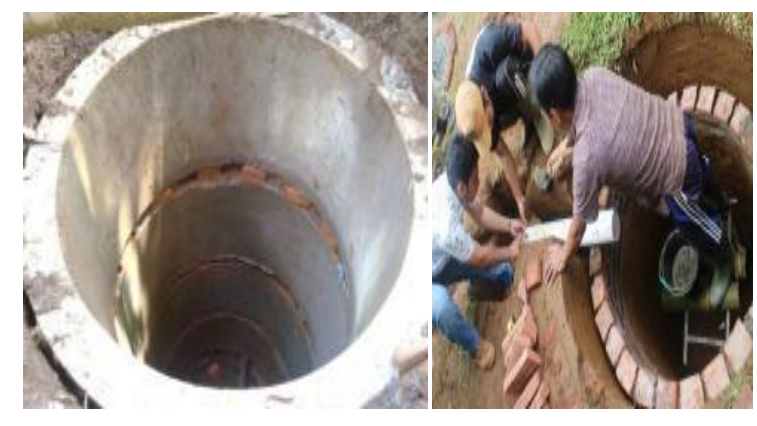

Gambar 2. Model Sumur Resapan dengan Konstruksi Bis, Batu Bata dan Corblock

Disamping IPAH dan sumur resapan dalam program PPDM ini juga dibangun saluran-saluran buntu (rorak). Saluran buntu (rorak) merupakan saluran yang buat untuk meresapkan air melalui parit-parit yang didalamnya diberi sumur-sumur dangkal (rorak) penampung air. Pembuatan saluran berorak dengan pertimbangan bahwa jika hanya dibangun sumur-sumur resapan individu di beberapa rumah warga maka belum efektif dalam mengurangi debit limpasan yang terjadi di seluruh areal padukuhan atau desa.

Pada prinsipnya, IPAH, sumur resapan maupun rorak berfungsi untuk menjebak aliran permukaan dan memberikan kesempatan kepada air hujan untuk terinfiltrasi ke dalam tanah.

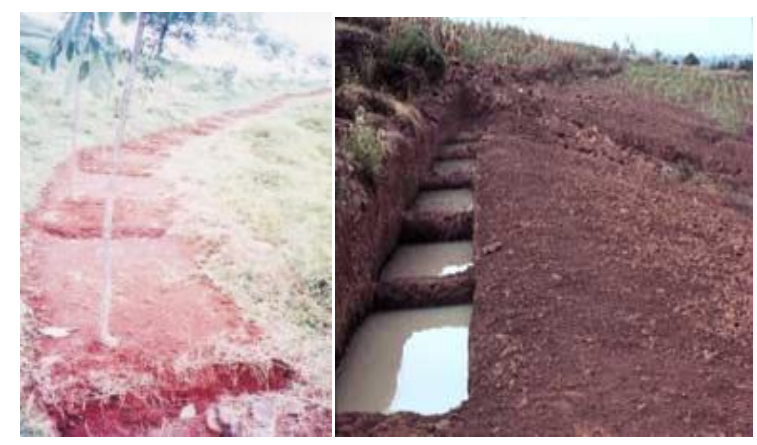

Gambar 3. Beberapa Model Rorak yang Dikombinasikan dengan Teras Gulud

\section{IPTEK Pemanfaatan Lahan Pekarangan}

Kegiatan utama program PPDM ini adalah transfer teknologi melalui pendidikan, pelatihan serta pendampingan untuk meningkatkan pengetahuan, pemahaman, dan kapasitas serta keterampilan teknis masyarakat dalam pengembangan teknologi tepat guna (TTG) salah satunya adalah hidroponik. Kegiatan pendidikan masyarakat dilakukan melalui penyuluhan tentang pengembangan teknologi hidroponik sayuran sekaligus mendukung pengembangan desa wisata berbasis pertanian. Sedangkan kegiatan pelatihan dilakukan melalui demonstrasi dan praktek secara langsung membuat nutrisi hidroponik sayuran organik dengan memanfaatkan bahan-bahan alami di sekitar lingkungan sebagai nutrisi hidroponik sehingga dapat menjaga keberlangsungan dan menghemat biaya produksi.

Beberapa keuntungan dari pengembangan teknologi hidroponik terutama pada sayuran secara organik antara lain sebagai berikut; (a) kebersihan tanaman untuk tumbuh dan berproduksi lebih terjamin; (b) lebih praktis didalam perawatannya dan gangguan hama lebih terkontrol; (c) penggunaan pupuk lebih hemat dan efisien; (d) lebih mudah mengganti tanaman yang mati dengan tanaman baru; (e) tidak membutuhkan tenaga kerja yang banyak; (f) tanaman dapat tumbuh lebih cepat dan bersih; (g) hasil produksi sayurannya lebih tinggi dan kontinu; (h) harga jual sayuran hidroponik lebih tinggi; (i) beberapa jenis tanaman dapat dibudidayakan diluar musim; (j) tanaman hidroponik dapat dilakukan pada lahan atau ruang yang terbatas. Sementara kelemahannya adalah sebagai berikut; (a) membutuhkan investasi awal yang mahal; (b) memerlukan keterampilan khusus terutama pada saat membuat ramuan nutrisinya; (c) ketersediaan dan pemeliharaan hidroponik tergolong rumit [17].

Pembuatan media bertanam hidroponik tergolong mudah. Teknis pembuatan media tanam hidroponik adalah sebagai berikut: (a) membersihkan lahan atau lokasi tempat pipa sebagai media tanam sayuran; (b) menyiapkan 
media hidroponik dengan menggunakan pipa; (c) media hidroponik menggunakan pipa-pipa yang disambung dengan pola berbeda. Pipa tersebut digunakan sebagai tempat untuk memasukan benih. Pipa dibuat lubang dengan diameter sekitar $4 \mathrm{~cm}$, kemudian dibagian ujung paling bawah pipa diarahkan ke dalam bak penampung air.

Metode hidroponik yang dipraktekan adalah metode NFT (Nutrient Film Technique) yaitu metode budidaya hidroponik dengan meletakkan akar tanaman pada lapisan air yang dangkal. Air tersebut tersirkulasi dan mengandung nutrisi sesuai kebutuhan tanaman. Perakaran dapat berkembang didalam nutrisi, karena di sekitar perakaran terdapat selapis larutan nutrisi. Tata cara penanaman pada media hidroponik dilakukan sebagai berikut: (a) pembibitan dengan memilih bibit yang berkualitas; (b) penyemaian sistem hidroponik menggunakan bak plastik yang berisi campuran pasir halus, sekam bakar, kompos dan pupuk kandang dengan perbandingan 1:1:1:1. Memasukan benih sayuran dengan jarak $1 \times 1,5 \mathrm{~cm}$ dan menutup dengan kain yang telah dibasahi. Membuka kain penutup dan siap menanam jika benih telah berkecambah; (c) menyiapkan media tanam yang mampu menyerap dan menghantarkan air, tidak mudah rusak, tidak mempengaruhi $\mathrm{pH}$ dan steril. Media tanam yang digunakan sabut kelapa dan sekam bakar. Kemudian mengisi polybag dengan media tanam yang sudah siap; (d) membuat green haouse atau rumah paranet; (e) memberikan pupuk yang kaya unsur hara makro dan mikro; (f) melakukan perwatan tanaman seperti pemangkasan, pembersihan gulma, penyemprotan pupuk dan lain sebagainya [17].

Nutrisi untuk budidaya hidroponik harus mengandung nutrisi esensial yaitu berupa unsur makro dan unsur mikro. Unsur makro terdiri dari $\mathrm{C}, \mathrm{H}, \mathrm{O}, \mathrm{N}$, $\mathrm{S}, \mathrm{P}, \mathrm{K}, \mathrm{Ca}, \mathrm{Mg}$. Sedangkan unsur mikro yaitu $\mathrm{Fe}, \mathrm{Mn}, \mathrm{Zn}, \mathrm{Cu}, \mathrm{Co}, \mathrm{B}, \mathrm{Mo}, \mathrm{Cl}$. Bahan yang dibutuhkan untuk membuat nutrisi hidroponik organik adalah sebagai berikut; (a) $300 \mathrm{~kg}$ kotoran kambing; (b) $500 \mathrm{~kg}$ jerami; (c) $100 \mathrm{~kg}$ arang sekam; (d) $100 \mathrm{~kg}$ dedak/ bekatul; (e) $300 \mathrm{gr}$ belerang; (f) $17 \mathrm{~kg}$ daun lamtoro/ kacang-kacangan; (g) 6 kg daun sirsak; (h) $2,5 \mathrm{~kg}$ tetes/ gula; (i) $1 \mathrm{lt} \mathrm{Em} 4 /$ mikroorganisme; (j) air bersih secukupnya. Cara pembuatannya adalah sebagai berikut; (a) mencincang daun lamtoro dan daun sirsak; (b) memasukan semua bahan ke dalam water turen atau terpal yang sudah dibentuk bak; (c) memasukan air bersih hingga kondisi macak-macak; (d) memberi udara dengan aerator hingga terjadi fermentasi aerob; (e) membiarkan selama 30 hari kemudian mengambil airnya dengan cara di saring.

Cara menggunakan nutrisi hidroponik adalah sebagai berikut: (a) mengambil larutan bagian atas yang tidak ada endapannya; (b) cairan hasil fermentasi diencerkan dengan perbandingan $1: 10$ (10 bagian air dan 1 bagian); (c) menggunakan larutan untuk penyiraman atau nutrisi hidroponik; (d) menggunakan untuk penyemprotkan tanaman; (e) menggunakan ampasnya untuk pupuk organik padat/ media tanam dalam pot [18].

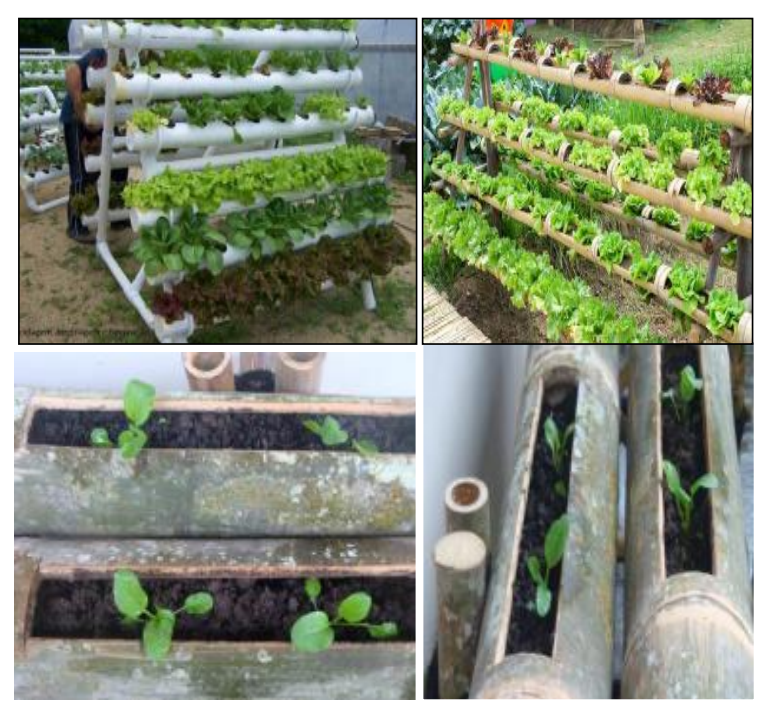

Gambar 4.Media Verticultur Berbahan Pipa Paralon dan Bambu 


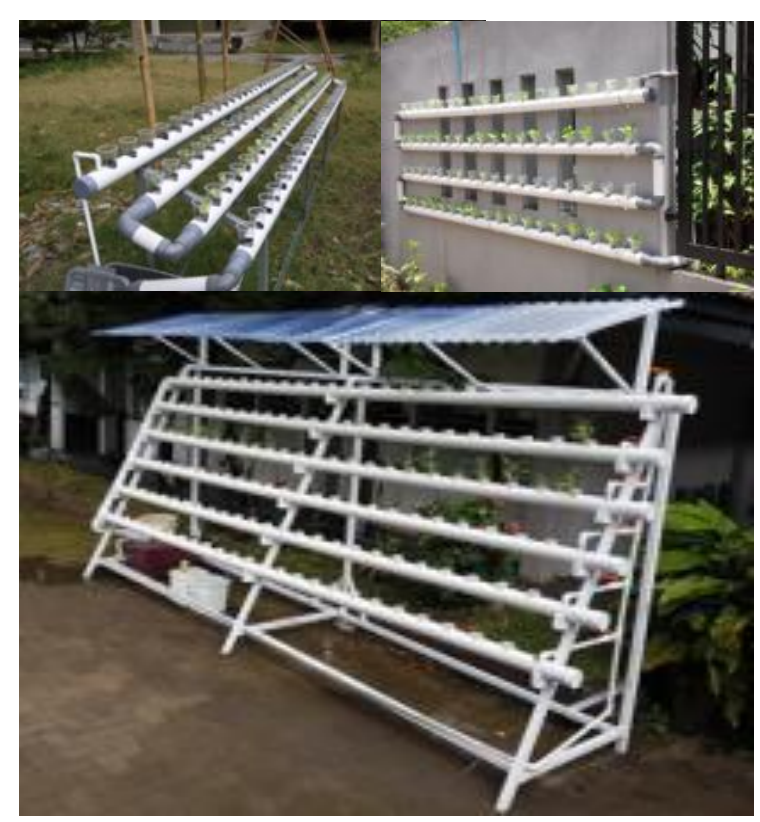

Gambar 5. Beberapa Model Media Hidroponik

\section{Pengembangan Desa Wisata Berbasis Pertanian}

Sebagai salah satu penanda (ciri khas) desa wisata dan sekaligus untuk dikembangkan sebagai komoditas unggulan, pemerintah desa Pandowoharjo sangat berharap dapat dikembangkan satu komoditas unggulan yaitu tanaman koro berikut olahannya. Berdasarkan pertimbangan bahwa tahu tempe sebagai produk olahan makanan tradisonal dan banyak dikonsumsi secara meluas oleh seluruh kalangan masyarakat Indonesia, kini mengalami kesulitan bahan baku kedelai. Satu sisi kebutuhan kedelai cukup tinggi, disisi lain produktivitas kedelai di Indonesia yang rendah, mengharuskan Indonesia mengimpor kedelai dalam jumlah besar. Solusinya, ada beberapa komoditi yang berpotensi menjadi pengganti kedelai, diantaranya koro pedang [19].

Koro pedang (Canavalia ensiformis) memiliki kandungan karbohidrat sebesar 45,2- 5,6\% dan protein 23,8-27,6\%, sehingga koro pedang dapat digunakan sebagai bahan baku produk protein rich flour (PRF) atau tepung kaya protein. Koro pedang juga memiliki produktivitas lebih tinggi dibandingkan dengan kedelai.
Produktivitas koro pedang merah (Canavalia gladiate) mencapai 720-1.500 $\mathrm{kg}$, berbeda dengan kedelai yang hanya berkisar antara 600-1.000 kg ha-1 [20].

Selain kandungan protein dan produktivitas yang tinggi, kemampuan tumbuh toleran pada kondisi ternaungi juga menjadi segi positif dari tanaman koro pedang. Tanaman koro pedang dapat tumbuh sampai ketinggian tempat 2.000 $\mathrm{m}$ dpl, dan tumbuh baik pada suhu ratarata $14 \mathrm{oC}$ hingga $27 \mathrm{oC}$ di lahan tadah hujan atau 12 oC hingga 32 oCdi daerah tropik dataran rendah. Tanaman koro pedang putih dapat tumbuh baik pada curah hujan tinggi $4.200 \mathrm{~mm}$ pertahun dan curah hujan rendah sampai $700 \mathrm{~mm}$ pertahun. Tanaman koro pedang juga dapat tumbuh baik pada tanah asam sampai dengan kondisi netral $(4,4-6,8)$ dan juga pada daerah tergenang dan salin [21].

Secara singkat, kegiatan yang telah dilaksanakan pada Tahun I dan hasilnya dapat ditunjukkan pada Tabel III.

TABEL IIIII

tahapan pelaksanaan, metode dan hasil

\begin{tabular}{|c|c|c|}
\hline Tahap & $\begin{array}{c}\text { Metode } \\
\text { Pelaksanaan }\end{array}$ & Hasil \\
\hline $\begin{array}{l}\text { Tahap } \\
\text { Awal }\end{array}$ & $\begin{array}{l}\text { a. Pendekatan dan } \\
\text { sosialisasi } \\
\text { program }\end{array}$ & $\begin{array}{l}\text { a. Apresiasi, kesiapan dan } \\
\text { penerimaan dengan baik } \\
\text { dari pemerintah desa dan } \\
\text { masyarakat tentang } \\
\text { program PPDM }\end{array}$ \\
\hline $\begin{array}{l}\text { Tahap } \\
\text { Pelaksa } \\
\text { naan }\end{array}$ & $\begin{array}{l}\text { a. Sosialisasi } \\
\text { tentang } \\
\text { program } \\
\text { transfer } \\
\text { teknologi } \\
\text { kepada } \\
\text { masyarakat } \\
\text { b. Kegiatan } \\
\text { transfer } \\
\text { teknologi dan } \\
\text { pendampingan } \\
\text { kepada } \\
\text { masyarakat } \\
\text { meliputi : } \\
\text { sistim panen air } \\
\text { hujan, budidaya } \\
\text { sayuran dengan } \\
\text { vertikultur dan } \\
\text { hidroponik }\end{array}$ & $\begin{array}{l}\text { a. Semakin bertambahnya } \\
\text { jumlah warga yang } \\
\text { memahami, dan } \\
\text { memiliki ketrampilan } \\
\text { dalam mensikapi } \\
\text { perubahan iklim } \\
\text { b. Jumlah sarana IPAH, } \\
\text { sumur resapan dan rorak } \\
\text { bertambah } 15 \text { unit } \\
\text { c. Jumlah warga yang } \\
\text { melakukan panen dan } \\
\text { memanfaatkan air hujan } \\
\text { meningkat ( } 15 \mathrm{KK} \text { ) } \\
\text { d. Jumlah anggota } \\
\text { kelompok wanita tani } \\
\text { yang memanfaatkan } \\
\text { lahan pekarangan dengan } \\
\text { budidaya sayuran sistim } \\
\text { vertikultur dan } \\
\text { hidroponik meningkat ( } \\
\text { 20 orang) }\end{array}$ \\
\hline
\end{tabular}


Sedangkan beberapa kegiatan lain yang merupakan kelanjutan program dari program Tahun I yaitu budidaya perikanan, peternakan, dan jamur; pengembangan kelembagaan unit bisnis; dan pengembangan pariwisata yang masingmasing akan dilaksanakan pada Tahun II dan Tahun III.

\section{KESIMPULAN}

Dalam mewujudkan desa wisata kampung iklimdi Desa Pandowoharjo, serangkaian program kegiatan dirancang dan dilaksanakan secara berurutan dan berkesinambungan. Pertama edukasi masyarakat tentang panen dan pemanfaatan air hujan untuk budidaya sayuran pada lahan pekarangan. Rancang bangun sarana pemanenan air hujan dilakukan dalam beberapa bentuk IPAH, sumur peresapan dan saluran buntu (Rorak) yang dibangun menyebar di enam padukuhan yang telah ditetapkan sebagai pusat pengembangan desa wisata.

Ketiga model sarana pemanenan air hujan tersebut dibuat sebagai bentuk edukasi baik bagi masyarakat desa Pandowoharjo maupun bagi para wisatawan yang datang berwisata dan belajar kearifan lokal yang ada di Desa Pandowoharjo.

Kelompok wanita tani sangat terbantu dengan sarana budidaya sayuran sistim vertikultur dan hidroponik. Sejumlah anggota yang sebelumnya tidak aktif, menjadi tertarik dan katif kembali dalam KWT.

Pengembangan komoditas unggulan desa berupa komoditas koro memiliki potensi dan peluang baik secara teknis budidaya maupun secara ekonomis.

\section{UCAPAN TERIMA KASIH}

Pada kesempatan ini kami Tim Pengabdi PPDM LPPM Universitas Janabadra mengucapkan banyak terima kasih kepada semua pihak yang telah membantu mulai dari perencanaan hingga terselengaranya kegiatan ini. Kepada masyarakat, Mitra hingga segenap aparat terkait : Desa Pandowoharjo, Kecamatan Sleman, Kabupaten Sleman yang telah memberikan kesempatan kepada Tim Pengabdi untuk bersama-sama mitra dan masyarakat melakukan kegiatan ini. Khususnya kepada DRPM Kemenristekdikti yang telah memebrikan dukungan dana bagi terselenggaranya kegiatan ini.

\section{DAFTAR PUSTAKA}

[1] Dwiratna NPS, Widyasanti A, dan Rahmah DM., "Pemanfaatan Lahan Pekarangan dengan Menerapkan Konsep Kawasan Rumah Pangan Lestari," Dharmakarya: Apliakasi Iptek untuk Masyarakat, vol. 5(1), no. ISSN 1410-5675, pp. 19-22, 2016.

[2] Kuswati, "Pemanfaatan Pekarangan Dalam Upaya Ketahanan Pangan Warga Desa Karang Gondang Kecamatan Karanganyar Kabupaten Pekalongan," Program Studi Pendidikan Geografi. Universitas Negeri Yogyakarta, Yogyakarta, 2016.

[3] B. Tresno Sumbodo, "Analisis Usahatani Pada Lahan Pekarangan. Studi Kasus di Desa Sumbermulyo Kecamatan Bambanglipuro Bantul D.I Yogyakarta," Program Studi Agribisnis. Fakultas Pertanian. Universitas Janabadra, Yogyakarta, 2014.

[4] Irwan SNR, Rogomulyo R. dan Trisnowati S., "Pemanfaatan Pekarangan Melalui Pengembangan Lanskap Produktif di Desa Mangunan, Kabupaten Bantul Yogyakarta," Jurnal Ilmu Pertanian Indonesia (JIPI), vol. 23(2), no. ISSN 0853-4217 DOI:10.18343/jipi.23.2.148, pp. 148157, 2018. 
[5] Anonim, "Peraturan Menteri Lingkungan Hidup dan Kehutanan Nomor: P.84/MenLHSetjen/Kum.1/11/2016 tentang Program Kampung Iklim," in Peraturan Menteri Lingkungan Hidup dan Kehutanan Nomor: P.84/MenLHSetjen/Kum.1/11/2016 tentang Program Kampung Iklim, Jakarta, Pemerintah Indonesia, 2016.

[6] Anonim, "Peraturan Pemerintah RI Nomor 43 Tahun 2014 tentang Peraturan Pelaksanaan Undangundang Nomor 6 Tahun 2014 tentang Desa," in Peraturan Pemerintah RI Nomor 43 Tahun 2014 tentang Peraturan Pelaksanaan Undangundang Nomor 6 Tahun 2014 tentang Desa, Jakarta, Pemerintah Indonesia, 2014.

[7] Anonim, "Monografi Desa Tahun 2017," in Monografi Desa Tahun 2017, Yogyakarta, Pemerintah Desa Pandowoharjo, 2017.

[8] Anonim, "Rencana Pembangunan Jangka Menengah Desa (RPJMDes) Desa Pandowoharjo Tahun 20152020," in Rencana Pembangunan Jangka Menengah Desa (RPJMDes) Desa Pandowoharjo Tahun 20152020, Yogyakarta, Pemerintah Desa Pandowoharjo, 2015.

[9] Anonim, "Rencana Pembangunan Jangka Menengah Daerah (RPJMD) Kabupaten Sleman Tahun 2016-2021," in Rencana Pembangunan Jangka Menengah Daerah (RPJMD) Kabupaten Sleman Tahun 2016-2021, Yogyakarta, Pemerintah Kabupaten Sleman, 2016.
[10] Dwi T, Sabariah M, M Bahrudin R., "A Study on artificial recharge well as a part of drainage system and water supply in UHTM," in National Seminar on Environment, Development, and Sustainability. 1:106-111, 2008.

[11] Arafat Y., "Reduksi Beban Aliran Drainase Permukaan dengan Menggunakan Sumur Resapan," SMARTek, vol. 6(3), no. 3, pp. 144153, 2008.

[12] Koesnaidi, Sumur Resapan untuk Pemukiman Perkotaan dan Pedesaan, Jakarta: Penebar Swadaya, 2011.

[13] Supardi, "Konservasi Air Dengan Sumur Resapan," Jurnal Akartika Magelang, vol. 34, no. 2, pp. 244-255, 2010.

[14] Anonim, “SNI No. 03-2453-2002," in Tata Cara Perencanaan Sumur Resapan Air Hujan Untuk Lahan Pekarangan, Jakarta, Bdan Standarisasi Nasional, 2002.

[15] Fakhrudin M, "Kajian Sumur Resapan sebagai Pengendali Banjir dan Kekeringan di Jabodetabek," LIMNOTEK, vol. 17, no. 1, pp. 8-16, 2010.

[16] Sitti Maryam Y., dan Niken Nur Kasim, "Pemanfaatan Pekarangan Menjadi Kebun Sayur Produktif Di Daerah Pesisir Di Kecamatan Wara Timur," Jurnal Pengabdian Masyarakat : To Maega, vol. 1, no. 1, pp. 1-7, 2018.

[17] Roidah, Ida Syamsu, "Pemanfaatan Lahan Dengan Menggunakan Sistem Hidroponik," Jurnal Bonorowo, vol. 1, no. 2, 2014. 
[18] Anonim, "Nutrisi Organik untuk Hidroponik," 2018. [Online]. Available:

http://himatan.ilmutanah.unpad.ac.id. [Accessed 26 Februari 2018].

[19] Mutthiah Putri S., Tatiek Kartika S., dan Abdul Qadir, "Pertumbuhan dan Pembungaan Tanaman Koro Pedang (Canavalia ensiformis) pada Kondisi Ternaungi dan Kombinasi Pemupukan Berbeda," Bul. Agrohorti, vol. 6, no. 3, pp. 382-387, 2018.
[20] Ekayane, S., K. Skog, N-G. Asp, "Canavanine Content In Sword Beans (Canavlia gladiata): Analisis and Effect of Processing," Journal Food and Chemical Toxicology, vol. 45, pp. 797-803, 2007.

[21] Puslitbangtan, "Pengolahan Kedelai Menjadi Berbagai Bhan Makanan," Pusat Penelitian dan Pengembangan Tanaman Pangan, Bogor, 2007. 